Klara SULIČ

Ana KUČAN

\section{Needs analysis for public green spaces in Grosuplje}

\section{Introduction}

The town under consideration is one of those Slovenian urban settlements and towns whose basic positive feature is that it is well-integrated into the space. Users of open spaces from whichever urban district can in several minutes and almost directly access natural and cultural landscapes in the environment which represent extensive recreational areas. The town is considerably green. There are a lot of free green areas within the settled areas with prevailing construction types, with free-standing single homes with gardens also considerably contributing to the green appearance. Such a type of construction means that the density of users of open spaces in Grosuplje is relatively low and that a large share of the population has personal gardens available to them for spending leisure time outdoors. What then is the need for public green areas in such a town and how important are they for the urban structure? It was assumed that the needs of residents of single homes and multi-storey dwellings differed; however, both groups expressed a need for planned public green areas. It was also assumed that the differences between the perception of the urban space and green areas could be observed between migrants and the locals. Based on the findings from the spatial analysis, the need for areas of public nature in the past was undoubtedly less expressed or poorly recognised, which is also one of many explanations of why their arrangement did not always successfully follow the rapid development of construction and why they were not treated in full and equivalently with other utilisations of space. Additionally, public green areas were not suitably maintained and although they had already been approved in building plans or envisaged in previous social plans, they were not realised. The weight of such decisions is thus that much greater, for these concern small settled areas which could be considerably impoverished through change, loss or non-fulfilment of individual contents. In addition, this town which is quickly developing, has never built-up a recognised image and must still do so. Suitably treated and planned green areas could thus help it create one.

The intention of the survey with the aid of questionnaires was to establish the attitude of the town's residents to the existing state of arranged green areas and open spaces and to also establish their needs for different types and quantities of arranged green areas. Through a spatial analysis of the town, the state of the green areas was assessed, namely from the aspects of landscaping, content, allocation throughout the town, spatial sub-divisions, urban appearance and from the aspect of users. The last was based on all previous aspects and additionally considered the remoteness of green areas from users. Considering the general spatial characteristics of Grosuplje, which as mentioned is a considerably green town, the survey focused on arranged and public green areas, which are designed and maintained public urban landscapes used by and accessible to all users. The intention was to emphasise the distinctness of these spaces from green areas on the town periphery. These are significant recreational areas which are poorly accessible for some users due to their remoteness and poor design that obstruct movement, spatial obstacles or other characteristics. Activities carried out in these areas and the manner of socialising differ from those in the town's green areas. The aim of the survey was to provide general guidelines for planning green and open spaces in Grosuplje on the basis of findings from the analytical part. Existing areas should thereby, as required, be quantitatively supplemented and all green areas and open spaces should be connected as a whole so as to be functional for residents and developmentally equivalent with all other utilisations of space, representing an important element of the town's appearance.

\section{Theoretical departure points for research}

Urban green areas are those spatial components that increase opportunities for residents to get together and socialise. These residents are not a homogeneous group, but consist of various age and user groups who possess a variety of needs, and various ways of expressing and prioritising the satisfaction of individual needs. Several of these needs are common to all people and concern basic human needs such as relaxation, comfort, employment, exploration, etc. (Polič, 1996), while other needs are unique and characteristic for individual groups and categories of residents. They may concern age, education, social status, profession, health status, etc. and, according to the survey, even whether someone lives in a single home or multi-storey dwelling. User groups also exist within spaces which are frequently overlooked for whom it is characteristic that they require arranged green areas in the close environment (Marcus and Francis, 1998) to satisfy their needs. These include disabled persons (elderly, handicapped, etc.), pre-school and elementary children and teenagers. B. Goličnik and I. Šuklje Erjavec (2006) caution that specific needs usually do not also mean a need for special spaces, but should be included in the entire planning and made accessible and useable to all. The integrity of urban green areas also refers to a system of various contents and allocations of green areas in the urban space that must be located at a suitable distance from users from the aspect of individual green areas for access and use for all is prescribed by elements which define a successful public open space. Urban green areas are a part of this. In literature (Francis, 2003; Goličnik, 2008; Polič, 2000), one of the key components for co-creating successful spaces is the established presence of users, whereby a variety of activities, programmes, city furniture, spatial sub-divisions as well as spatial planning and maintenance will have an effect on the diversity of user groups. B. Goličnik (2006), while analysing squares and parks, established that public urban spaces are successful and vital whenever three types of characteristic activities are simultaneously present: long-term activities, passive activities and 
activities during transit through the spaces. In short, public open spaces and green areas are successful or suitable whenever they are a response to users' needs. This means that these needs are successfully fulfilled and, as established by Polič (2000), encourage positive social interaction. People thus also spend time in and use such spaces. Alongside all the aforementioned potential and opportunities that a space can offer, the users are ultimately those who create an effective environment, spaces for actual use and fulfilled and utilised opportunities (Goličnik and Šuklje Erjavec, 2006).

Suitable and at the same time aesthetically planned urban green areas that are a response to user needs, not only contribute to a higher quality living environment but also to a good and recognised urban image. The latter is an interlaced arrangement/composition of open space, architectural design and urbanism. The image that is also defined by the system of urban green areas can already be visible on the planning level. This is displayed in the system's structure, namely in the composition, allocation, hierarchy and mutual relationships between open spaces and the attitude towards built-up spaces or structures that originates from natural characteristics of the space. In the narrower sense, urban appearance should also be understood from the aspect of awareness and use of the space through which we move. Green areas contribute to the above with their size and visual recognition and through mutual connections and connections with the urban periphery and built-up areas. Other components of this image also include individual details regarding the design method with green areas, the arrangement and maintenance of individual significant spaces in the city. In addition to central urban park spaces, K. Dimitrovska Andrews in K. Repič Vogelnik (1995) also list arrangements in front of buildings of public nature, tree avenues, key urban roads, key connecting pedestrian and cycling paths, banks of water courses, entrance to the city and city periphery, views and vistas of key recognisable elements of the city, etc. If the urban settled area is small, the significance of such arrangements is even stronger while the arrangement of open spaces must be adapted to the particular problems and potential of a city.

\section{Spatial analysis}

\subsection{Work method}

In order to understand the urban development of the natural and cultural features of Grosuplje, the spatial analysis initially included an assessment of written sources and cartographic materials ${ }^{[1]}$. In continuation, the majority of work comprised a terrain study of the town and a separate analysis of green areas together with open spaces. Based on the theoretical departure points, detailed criteria for observing and inventorying contents, arrangements and use of green areas were defined:

- the area is a designed space in the urban landscape;

- the contents emphasising a social connection role are defined;

- the area is used by the public;

- the presence of seating (number and allocation);
- the presence of city furniture (benches, trash bins, lighting, water motifs, sculptures, etc.);

- gathering points (number and allocation);

- visibility of the area;

- accessibility (physical and visible);

- the number of users;

- the manner of spatial use (transit through the space or spending time in the space).

The examination was repeated twice in the spring, specifically in the afternoon during the week and morning on the weekend. The age of user groups which spent time or passed through the areas was also recorded: children, youth, adults or elderly people. Based on the collected data, the areas in Grosuplje which comprised actual arranged public green areas and their state were later determined. The selection was then used in analysing allocation and accessibility to individual types of green areas - everyday use areas, sport fields and children's playgrounds. (Semi-public) green areas of residential areas were also treated, since the inventorying was performed on the basis of the criteria above, which define arrangement and use of spaces. Private areas were not included in the detailed analysis.

\subsection{Findings}

\subsubsection{Residential area green areas}

Single homes with gardens compare $89 \%$ of the residential areas in Grosuplje. These areas are, in comparison to the entire urban area and in comparison to areas with multi-storey dwellings, relatively large, quite similar to each other and not sub-divided. The only public areas and "children's playgrounds" in these areas were once streets and are becoming more and more burdened by traffic. Instead of bringing people together, this is decreasing social contact between them. The single home residential areas, as a rule, also do not possess semi-public green areas where various user groups could interact and spend time. Residents can satisfy a large number of needs for outdoor leisure time in gardens, also fulfilling the need for privacy. However, a private garden does not enable spontaneous meetings and social activities with a wider circle of people or other selective and special activities or various forms of recreation. Therefore, we can surmise that residents of such residential areas as well as those of multi-storey dwellings require semi-public and public green areas in their surroundings or town. Mlinar (1972; source: Doležal, 1991) also established via surveys that residents of single homes and multi-storey dwellings visited public park areas equally frequently. Considering the established spatial characteristics in single home residential areas in Grosuplje, it can be said that the arrangement of semi-public green areas would improve the structure and attraction of both the narrower and broader space. The space would thus be broken-down with contextual and design emphases installed and a new unique element given to the individual area.

Semi-public green areas alongside multi-storey dwellings are, in general, relatively qualitatively arranged. They include areas for children to play, gardens and possibilities for socialising and get-togethers and are least suitable for youth get-togethers. 

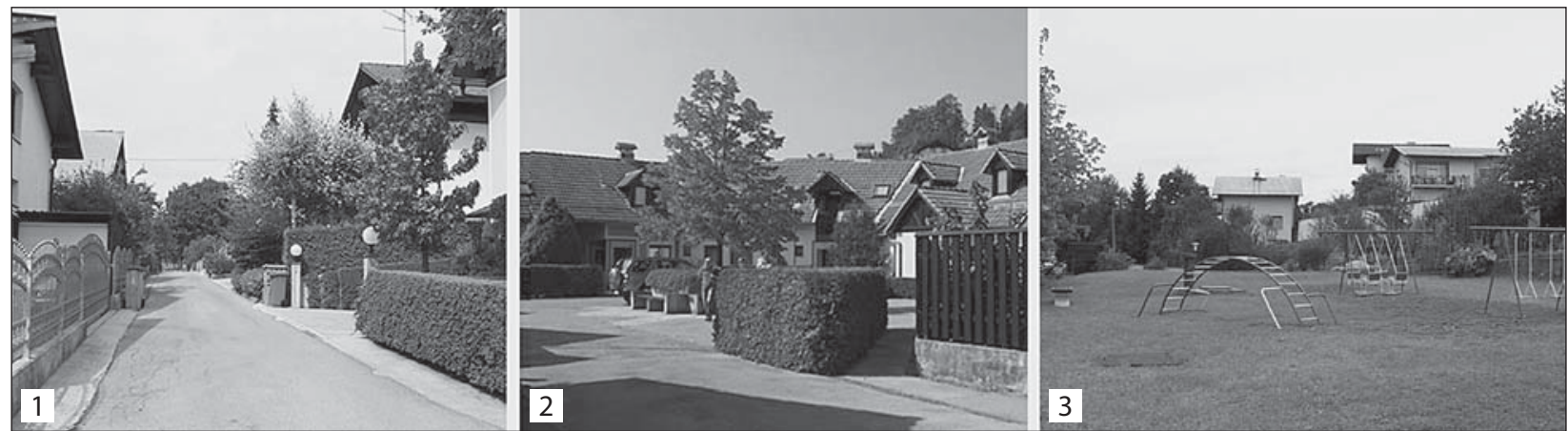

Figure 1: 1 - open single home residential area; 2 - only case of a single home residential area containing such a space (Dvori, urban designer: Alojzij Drašler); 3 - semi-public green areas alongside multi-storey dwellings (photo: Klara Sulič).

They are usually separated from traffic surfaces, nevertheless in recent years with increased traffic, problems have arisen regarding parked automobiles on green areas and even children's playgrounds. Considering the findings arising from observation, the reason can, among other things, be found in the lack of parking spaces with regard to increased motorised traffic and residents' unwillingness to park their vehicles farther away in free public urban parking areas. In Grosuplje, it is characteristic for green areas and particularly children's playgrounds to be alongside multi-storey dwellings; despite their semi-public nature and purpose, they also serve the wider surroundings and residents of neighbouring residential areas: single home residential areas. The role of such areas in the city is thus broader; however, this does not mean that the town does not also require public green areas (and children's playgrounds).

\subsubsection{Arranged public green areas}

Arranged public green areas are a part of the designed space of city landscapes. Upon observing arranged green areas on the urban level, questions arise regarding which areas in

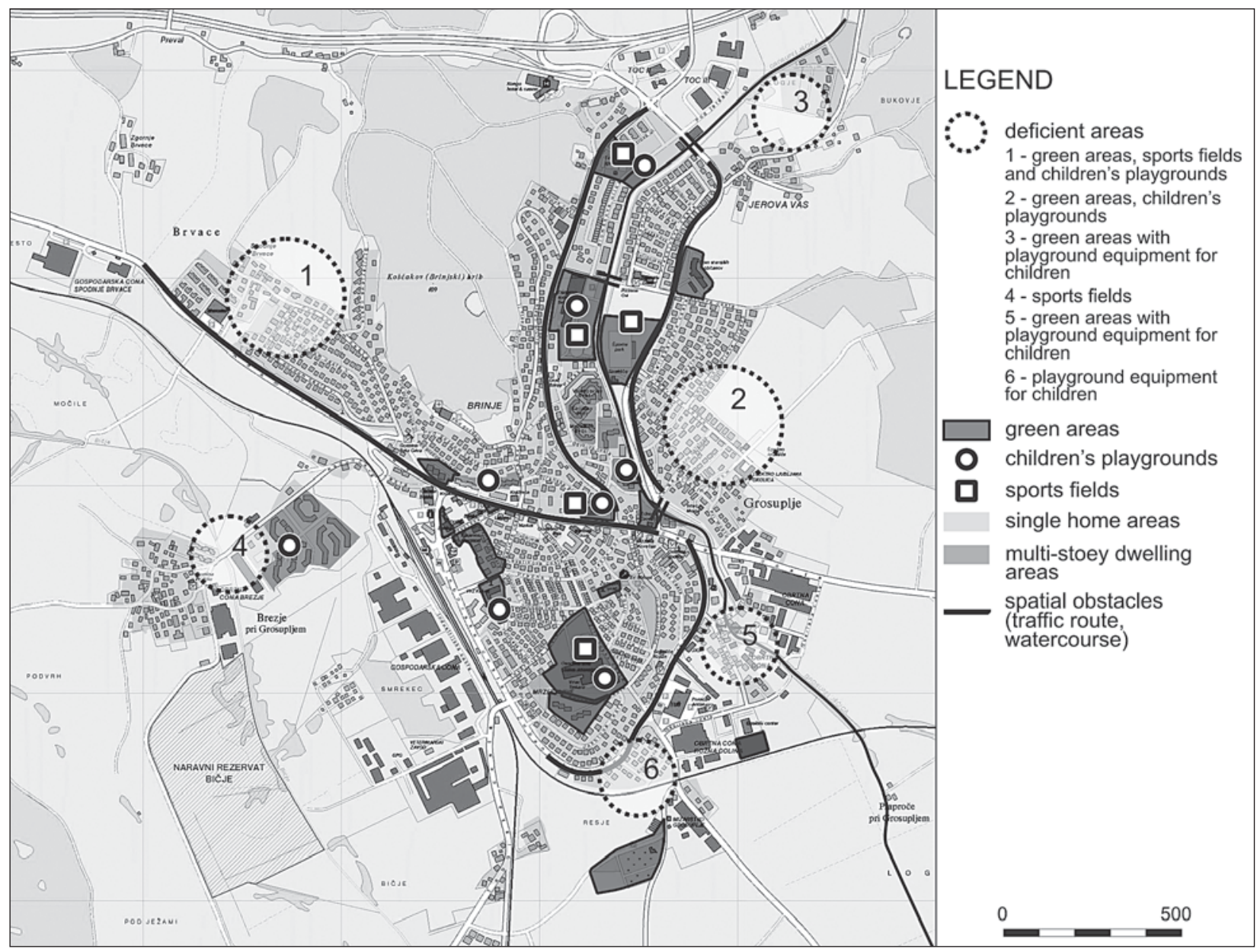

Figure 2: Areas lacking arranged public and semi-public green areas were acquired on the basis of analyses of spatial obstacles and the allocation and remoteness of green areas from users. 
Grosuplje are actually public and accessible to all users and how diverse the contents of individual green areas or urban spaces are in general. The findings are as follows:

1. Arranged green areas in Grosuplje are allocated alongside buildings of a public nature (schools, kindergartens, homes for the elderly, the municipal building and bank), sports fields (soccer and tennis), cemeteries and two smaller paved but park-oriented arrangements.

The soccer field and tennis courts are special areas with limited access based on payment or reserved for members of the soccer club. The landscape in front the home for the elderly is primarily intended for residents of the institution and is not connected to the surroundings and possesses a representative nature, such as the green area in front of the municipal building and arrangement in front of the bank. The last perhaps most suits the activities of various groups of users. All the areas of these arrangements are small and possess numerous elements of interest to users: pavement, stairs, path, green plot, memorial, benches and vegetation. All together, these elements create a dynamic and divided space, which above all is located alongside the most important pedestrian routes in the town: between the central part and train station. The user groups observed in the space were elderly people and other adults, mothers with children, skateboarders and teenagers. This is an important fact, considering that the majority of green areas in the town are not arranged in a manner that would encourage youth to socialise. Sports areas alongside schools where youth commonly gather are areas of active participation and, as later described, points for gathering and events which would encourage passive participation are lacking here. Nevertheless, areas alongside schools and kindergartens have for some time been the key hub of arranged urban green areas and also social interaction in Grosuplje. The first schools and kindergartens with appertaining outdoor areas were constructed quite early when the need for additional sports and children's playgrounds outside the scope of such institutions was non-existent. Such arranged areas for sports, recreation and rest have limited access in terms of time and are limited to the afternoon and weekends when there are no classes. From this aspect, we cannot consider them to be true public areas. Actual public green areas thus remain as cemeteries and smaller park arrangements.
2. Grosuplje thus possesses a lot of green areas, but which are deficient. The initial doubt that suitably arranged areas in the town that could effectively serve the needs of users can thus be partially confirmed. In the last two decades, with the rapid growth of the town and expansion of residential areas (construction of single homes and multi-storey dwellings), the relationship regarding the allocation of arranged public green areas has been changing. Analyses of their remoteness from users and the crossing of the most heavy traffic routes has shown that areas for daily use or semi-public areas in the form of smaller green arrangements, city furniture and children's playgrounds are lacking in residential areas at the town's periphery. Sports fields are needed in the Sončni dvori residential area, which is separated from the town by the railway.

From analyses according to criteria for establishing arranged public green areas, it can thus also be established that problems regarding these areas not only concern the quantity, but particularly the poorer maintenance thereof (dilapidated city furniture, emptying of trash bins, etc.), deficient fittings (predominantly the lack of benches) and less suitable design (lack of sub-areas, break-down) of existing spaces.

3. Areas alongside schools and kindergartens are the largest central green areas in the town containing playgrounds, large grass areas with paths and rich landscaping. Such areas are extremely open and aesthetically attractive. Here we are speaking of those positive design and structural spatial features that could prove interesting and attractive green areas for users. Observation has shown that activities on these places are connected to long-term active participation in sports and are concentrated around playgrounds, while the remaining space is not exploited. B. Goličnik (2006), in addition to the three characteristic types of activities which should be carried out on successful and vital spaces, also emphasises the appropriate break-down of space that these various forms of activities encourage. The enablement of passive participation (sitting on benches, laying on the grass, observation, etc.) in the treated areas alongside school activities during passage through the space is ignored. This is partially due to the quantitative lack and unsuitable installation of city furniture and partially also due to the structure of individual areas. Regarding the spatial characteristics
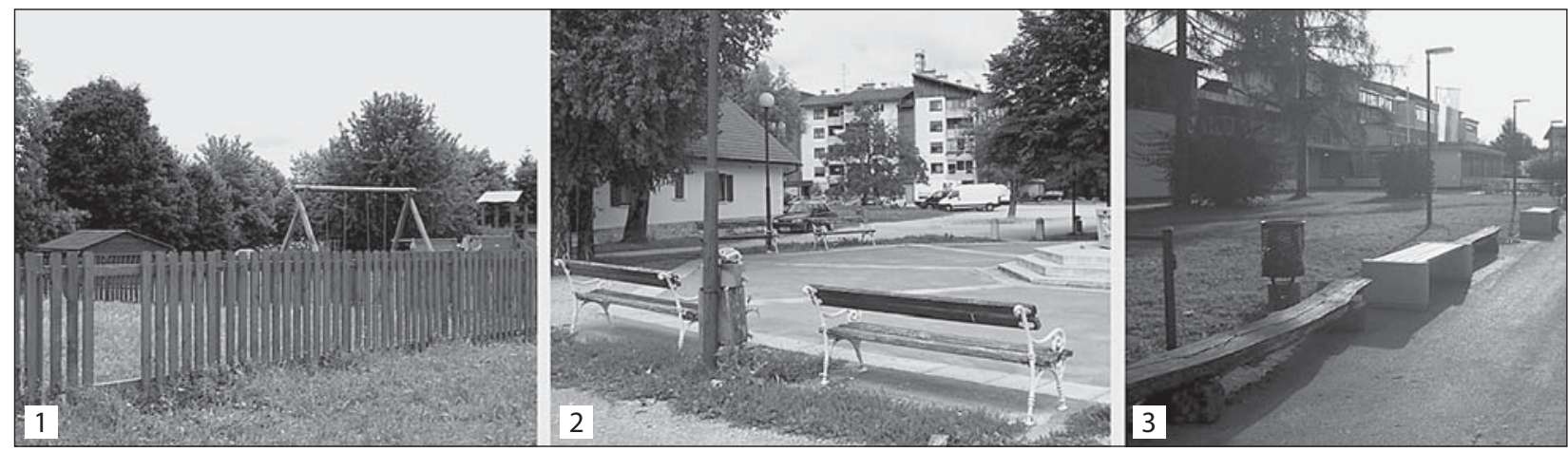

Figure 3: 1 - sports areas alongside schools and children's playgrounds alongside kindergartens are fenced and publicly accessible only in defined time periods; 2 - example of poorer maintenance of areas and city furniture at central green areas, such as schools and the square (photo: Klara Sulič). 
of the entire urban area - lack of diversity and emphasis on a standardised settled area - large and spatial grass areas are of extraordinary importance, but are probably less attractive for passive use from the aspect of users. It is estimated that a sub-division into smaller tree or bush groves and particularly more appropriate city furniture would increase possibilities for passive use of space. Users are, in such a case, less exposed to remaining participants and can take part in events in a more passive manner.

4. Park arrangements that were defined as public in the analysis, presently offer opportunities with which the town must plan contextually and design qualitative urban green areas in the future in connection with other green areas (main tree avenue, green areas alongside the Grosupeljščica stream). Both arrangements are expressed transit areas, while one of them, the square, is also a gathering area. Both areas should, in terms of design and programmes, enable more gathering and social activities, at the same time satisfying necessary activities when in transit through the area.

\subsubsection{Green areas in the role of co-creating the town's appearance}

This article highlights only the most obvious deficiencies of Grosuplje's appearance that were established through the spatial analysis: entrance and central areas. Both have significant effects on how one experiences the town, especially since distances in it are small and only a short period of time is required to go from one entrance to the other. All entrances to Grosuplje are characterised by business-commercial zones and large automobile distributor parking lots. The areas are poorly structured and visibly exposed; therefore, the arrangement of space and roads with green sub-divisions in these locations is urgently needed. A second deficiency is the contextual and physical lack of design of the town centre. Green areas could, in this case, particularly improve the structure of space in Grosuplje which must acquire a unique image in comparison to the remaining parts of the town. Numerous architectural changes are planned and the spatial confines considerable. From this aspect, the arrangement of open spaces (lawns, pavements, landscaping, benches, etc.) in front of planned new buildings of public nature must urgently obtain a broader socially-oriented role and not only an aesthetic one. From the aspect of pedestrians, such urban central areas with a concentration of service activities will enable more qualitative and interesting connections with both rest and recreation and residential areas. Movement in the town will thus be more attractive for pedestrians.

\section{Research study}

\subsection{Work method}

The intention of the shorter research survey, using a questionnaire, was to obtain information on the residents' of Grosuplje attitudes towards the existing state of arranged green areas, how often they used them, which areas and contents they lacked and how they assessed the town's appearance. The results of the survey were later used in the spatial analysis to design a concept and guidelines for planning green areas
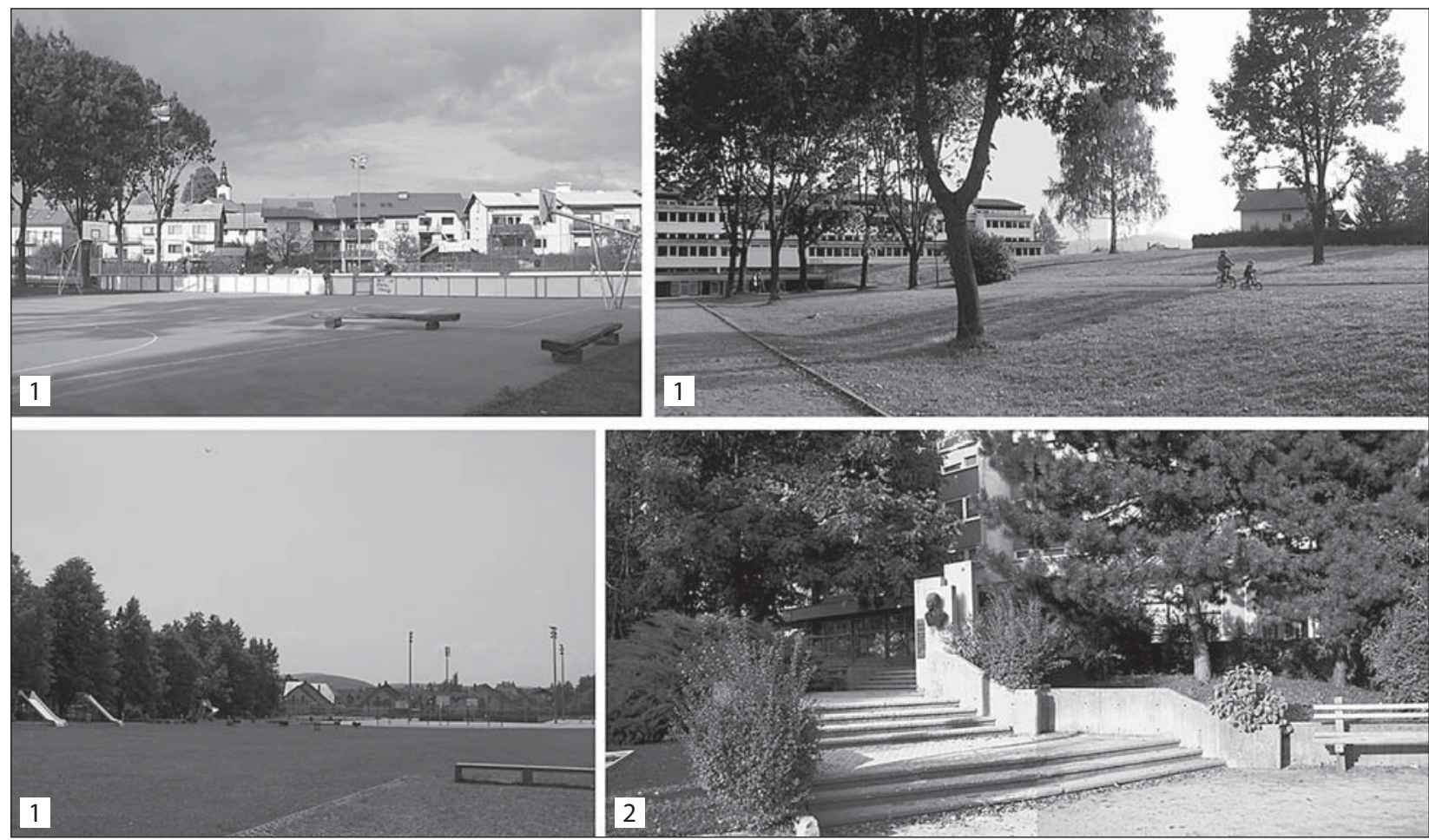

Figure 4: 1 - areas alongside schools which encourage particularly active participation and are less passive in nature. Benches, for example, are only located in the direct proximity of sports fields and playgrounds; 2 - example of arrangements in front of buildings of public nature used by various groups of users and encouraging all three types of activities (photo: Klara Sulič). 
and the open spaces in the town. Considering the spatial characteristics of the town, the prevailing share of single home construction between residential areas and a large share of migrants had the following questions during the departure points for the survey:

- Do people who live in single homes express an identical need for public green areas as residents of multi-storey dwellings?

- Which areas need improvement according to the first and second group of users?

- Do differences in attitude towards green areas also arise between groups of migrants and locals?

The survey was designed so that upon analysing the results, the attitude between the aforementioned pairs of user groups (residents of single homes - multi-residential dwellings, migrants - locals) could be verified. Among the migrants, those surveyed had lived in the town less than 15 years. Later, attitudes by age group and gender were also assessed. Since the number of respondents was small, the results in general only indicated differences between the stated user groups that could not be confirmed. Therefore, verification by user groups are presented for those where the differences are most pronounced. The results ascertained from the survey are general.

Based on the departure points and purposes, a questionnaire containing ten questions and sub-questions was prepared. These included close-type questions, thus questions providing a selection of answers and questions designed according to socio-spatial forms on which those surveyed drew in their answers on a map of the town. Contextually, the questions were divided into four sets: awareness and characteristics of the town as seen by migrants and locals; the town's appearance, including new settlement interventions; arrangement and need (where, how many) green areas in Grosuplje and socio-demographic characteristics. The first three sets will be presented in continuation, with awareness and appearance presented together. In addition to the survey responses, the comments of respondents with regard to the treated theme were also concurrently recorded.

The survey was carried out on the field, throughout the entire area of the town in the first half of 2006. Those interviewed were selected at random or according to the so-called snowball method, via the social network.

\subsection{Results}

Appearance, awareness and characteristics of the town comparison between migrants and locals

Those surveyed assessed appearance and awareness and denoted the characteristics of the town based on six questions. The survey also included questions in which they had to assess individual scenes or arrangements in the town viewing photographs.

It was found that Grosuplje was most known for its traffic arrangement and accessibility. These are the characteristics that stood out the most in terms of frequency among the 95 items. Both migrants and locals felt the town's biggest advantage to be its proximity and good connection with Ljubljana. Among the most obvious characteristics, both groups also indicated non-arranged roads, cycling and pedestrian paths. Comments given by migrants included that the town had not proved to be as promised, that is a pleasant, safe and peaceful green town. Comments of locals included the conviction that the town was changing due to migrants and that the municipality that had invited them there had not ensured basic things such as an arranged infrastructure. From the comments, it can be concluded that respondents did not feel comfortable as pedestrians in such a space and that the unarranged infrastructure prevented them from moving through the space on foot. Thus, the prerequisite for continued arrangement of the open space and green areas in Grosuplje is that the traffic system and infrastructure be improved, which will give pedestrians a feeling of safety and a pleasant space. Differences between migrants and locals were most obvious in this set of questions; however, they were not characteristic. Thus, we can only partially confirm the assumed differences in perception of space between these groups of users. The differences among the remaining groups assessed were not characteristic.

Table 1: Characteristics of Grosuplje as denoted by migrants, locals and both together. The most frequently expressed characteristics are shown.

\begin{tabular}{|l|l|l|}
\hline Migrants & Locals & Total \\
\hline $\begin{array}{l}\text { proximity to } \\
\text { connectiona (access, } \\
\text { migration) }\end{array}$ & $\begin{array}{l}\text { non-arranged } \\
\text { roads, cycling and } \\
\text { pedestrian paths }\end{array}$ & $\begin{array}{l}\text { non-arranged } \\
\text { roads, cycling and } \\
\text { pedestrian paths }\end{array}$ \\
\hline $\begin{array}{l}\text { non-arranged } \\
\text { roads, cycling and } \\
\text { pedestrian paths }\end{array}$ & $\begin{array}{l}\text { proximity to } \\
\text { Ljubljana (access, } \\
\text { connections, } \\
\text { migration) }\end{array}$ & $\begin{array}{l}\text { proximity to } \\
\text { Ljubljana (access, } \\
\text { connections, } \\
\text { migration) }\end{array}$ \\
\hline Kongo Casino & $\begin{array}{l}\text { rapid growth and } \\
\text { development } \\
\text { (immigration, new } \\
\text { construction) }\end{array}$ & $\begin{array}{l}\text { rapid growth and } \\
\text { development } \\
\text { (immigration, new } \\
\text { construction) }\end{array}$ \\
\hline $\begin{array}{l}\text { natural } \\
\text { environment and } \\
\text { agricultural region }\end{array}$ & $\begin{array}{l}\text { overnight } \\
\text { accommodation for } \\
\text { Ljubljana }\end{array}$ & $\begin{array}{l}\text { overnight } \\
\text { accommodation for } \\
\text { Ljubljana }\end{array}$ \\
\hline Louis Adamič & $\begin{array}{l}\text { Grosupeljščica } \\
\text { stream }\end{array}$ & $\begin{array}{l}\text { Koščakov hill and } \\
\text { Grosupeljščica } \\
\text { stream }\end{array}$ \\
\hline
\end{tabular}

Green areas also appeared in responses regarding the town's characteristics. The Koščakov hill and Grosupeljščica stream were among the most frequently mentioned. From Grosuplje's history, it can be ascertained that residents have informally used the two as recreational areas for quite a number of years. Informally, predominantly because the areas were not maintained as recreational areas and users adapted them to their needs - beating out paths, access paths to the water, etc. The spatial analysis showed these two areas to be the central green areas of the town. The Grosupeljščica stream is also a key connecting element for 
a number of green areas in the town. From this aspect, deliberation on the design of a larger central park and recreational areas for the town is prudent. This concerns more than just the size of the areas for an effective structural and contextual connection to existing open spaces (also the inclusion of arrangements in front of the home for the elderly in the wider system) and green areas, inclusive of improved quality of these areas. Such an approach would increase interest in and potential use of areas by users in general and also represent one of the central elements of the town's appearance. The aim of such an approach is also to create a more dynamic urban open space that would be suitable for social contact. The opinion arose in the survey responses that the town still possessed a more rural nature and that the open space did not suitably satisfy areas suitable for socialising.

In terms of the town's appearance, only a general finding from the responses can be established; specifically, that those surveyed were aware of the spaces they found most attractive, those which were poorly arranged (the Koščakov tree avenue, the park alongside the square, the Grosupeljščica stream area) and that they were aware of the main urban road and entrances to the town as less attractive and arranged. The findings partially conform to the findings of the spatial analysis.

Need for planned green areas - comparison between the needs of the residents of both single homes and multi-storey dwellings

The need for green areas, satisfaction with the arrangements and quantity of such areas, frequency of visits, areas visited and suggestions on the installation of individual types of green areas were assessed by the respondents within the scope of five questions. Findings on needs, satisfaction and suggestions are presented below. Since the responses to the research surveys express the ideas, wishes and expectations of the users of the space that can also quickly change, this set of questions was posed twice. The initial questions assessed the respondents' opinions on the significance of individual types of green areas in cities in general while subsequent questions were focused on Grosuplje. The respondents, for example, might feel urban parks to be very important, but feel that Grosuplje didn't require any parks. In this case, we could conclude that the areas in Grosuplje as such already satisfied the needs of the respondents. A map of the town was used to record responses for this set of questions.

From the responses, it was concluded that the respondents felt the green areas and open spaces of Grosuplje to be poorly planned in general. Arrangements alongside streams, cycling and pedestrian paths in the town, park areas and recreational paths in nature were highlighted among the individual types of green and open spaces. Comments recorded included disapproval of the construction of embankments and the polluting of the Grosupeljščica stream. This opinion is confirmed by the spatial analysis. Since flooding of Grosuplje must be taken into consideration when arranging waterfront areas, such an expansion of settlements means a smaller possibility for introducing public content, arrangement of access to waters, design of recreational-park arrangements along the stream and finally, decreased meaning of nature in the town. From the responses recorded on a map regarding respondents' suggestions on where new green areas in the town should be installed, the Grosuplejščica area stood out

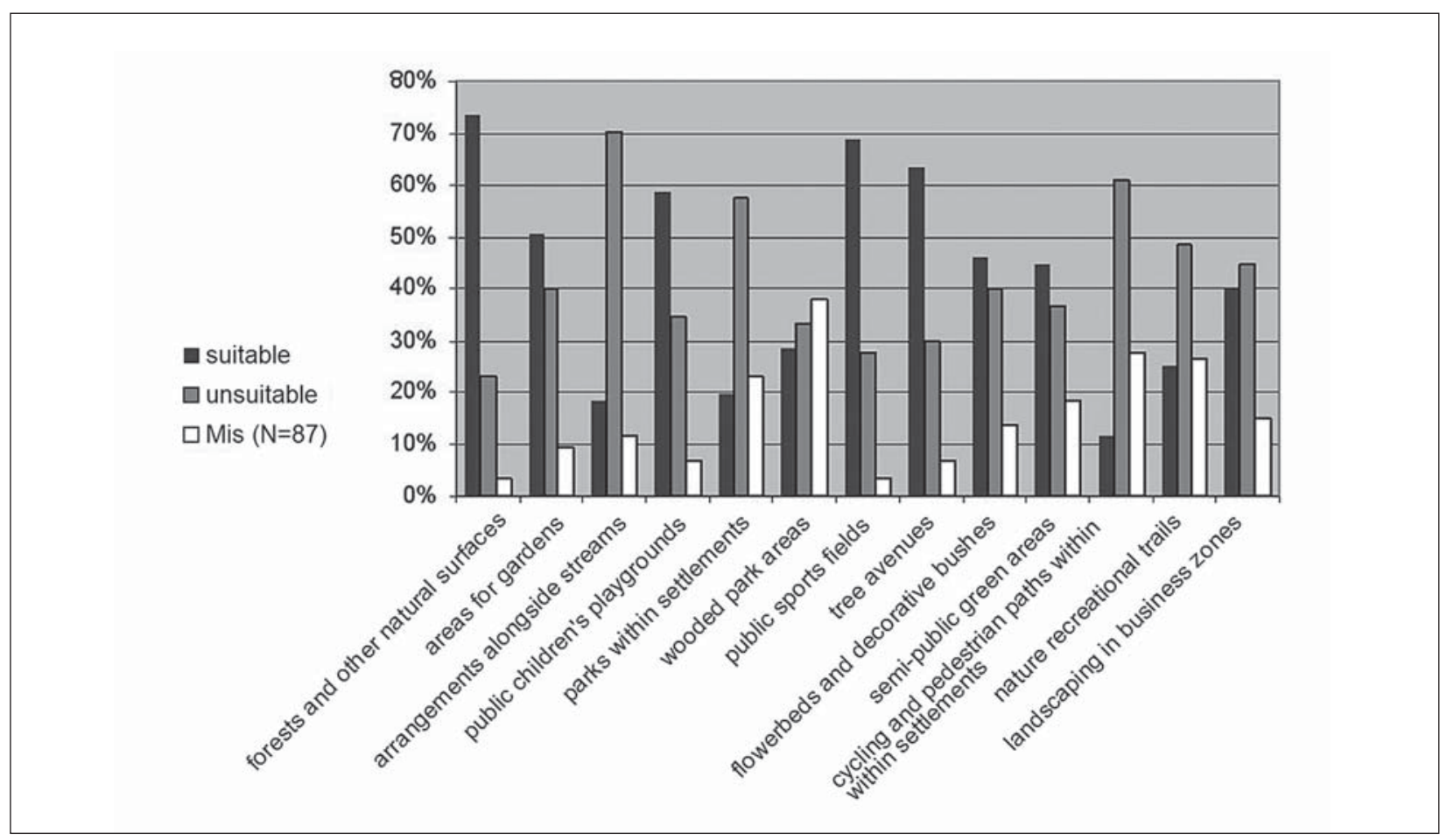

Figure 5: Opinions of the respondents regarding the suitable arrangement of various types of green and open spaces. (Un)suitability is shown as percentages within individual types and is comparable to percentages within remaining types. 


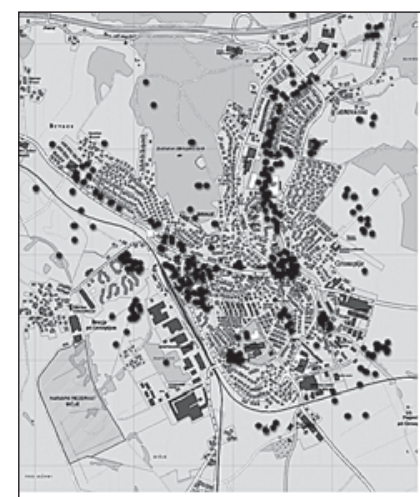

parks

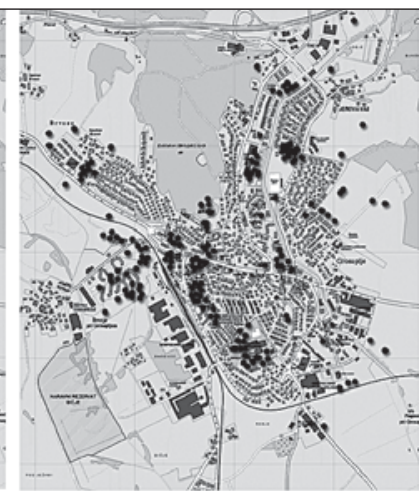

children's playgrounds

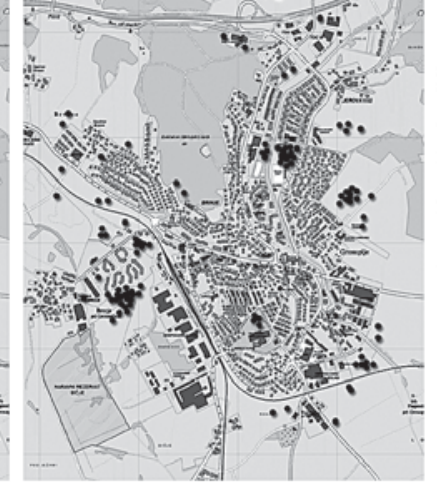

sports fields

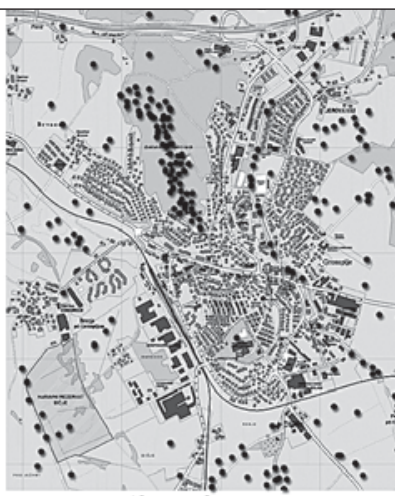

recreational areas

Figure 6: Opinions of the respondents regarding the installation of individual types of green areas.

as an area of parks and recreation. The suggestions were based on the respondents' assessment of the need for areas in certain parts of the town, regardless of where they resided. Nevertheless, it could be observed that the majority first thought of their direct residential surroundings and only subsequently of the town as a whole. The suggestions of the respondents were later considered in the analysis of deficient green areas as an additional rationale and confirmation of the findings of the spatial analysis. Due to the aforementioned subjectivity and characteristic responses, they were not directly included in subsequent work, but critically summarised. The comparison between individual groups of users within the scope of arrangements and suggestions did not show any distinguishing differences.

In addition to the suitability of the arrangement of green areas and open spaces, the respondents also assessed the (un)suitable quantity of such spaces. Among the most frequent responses was that certain areas lacked arrangements alongside streams, cycling and pedestrian paths in the town and park areas. A comparison between residents of single homes and multi-storey dwellings show differences that again are not statistically characteristic. We can therefore confirm the supposition that public green areas were deemed lacking by respondents who lived in multistorey dwellings as also by those surveyed living in single homes, the latter showing a need thereof. From the comparison, we can conclude that, according to the opinion of the first group, green areas such as parks, flowerbeds, semi-public areas, etc. were lacking the most. These are areas on which the respondents could participate actively or passively, in which they can find privacy or company and areas which satisfied their need for aesthetics. Many comments indicated that flowerbeds improved the town's appearance. According to the opinion of respondents living in single homes, deficiencies in the town and their periphery were particularly recreational areas on which they could satisfy those needs a private garden did not. Regarding attention to design and contents of the open spaces and green areas out of the aforementioned findings, it can be concluded that both groups of respondents ascribe nearly identical weight to this. The assumption that the needs of residents of single homes and multi-storey dwellings differed can be partially confirmed by this survey and dictates that a whole approach to planning and arranging green areas in this town is required. Differences between the user groups in terms of age were in this set of questions only denoted and not characteristic. This depended on whether an individual group felt a deficiency of more recreational areas (adults) or other design elements such as parks, arrangements alongside streams, children's playgrounds, etc. (youth up to the age of 25 and older people).

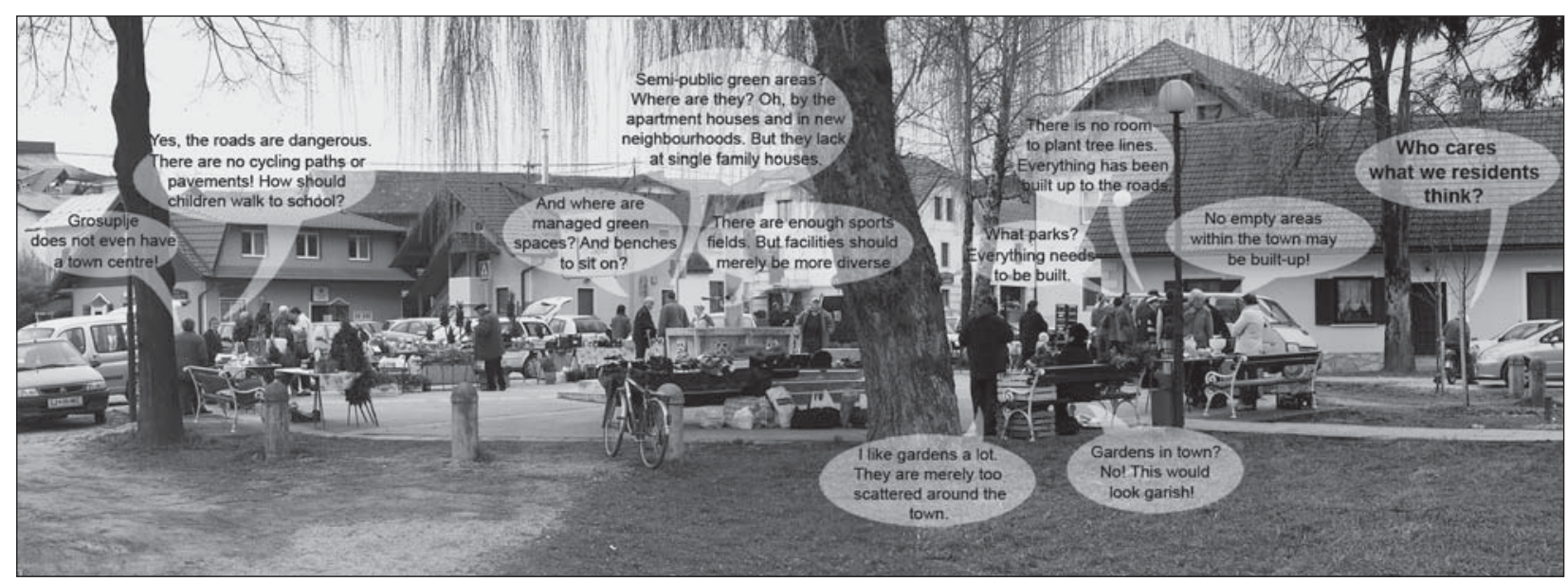

Figure 7: Several characteristic comments of respondents presented as a comic (photo: Klara Sulič). 
Table 2: Expressed need for green areas based on type of building the respondent lived in.

\begin{tabular}{|l|l|l|}
\hline Single homes & Multi-storey dwellings & Total \\
\hline $\begin{array}{l}\text { cycling and } \\
\text { pedestrian } \\
\text { paths within } \\
\text { settlements }\end{array}$ & $\begin{array}{l}\text { parking areas within } \\
\text { settlements }\end{array}$ & $\begin{array}{l}\text { cycling and } \\
\text { pedestrian paths } \\
\text { within settlements }\end{array}$ \\
\hline $\begin{array}{l}\text { arrangements } \\
\text { alongside } \\
\text { streams }\end{array}$ & $\begin{array}{l}\text { cycling and pedestrian } \\
\text { paths within } \\
\text { settlements }\end{array}$ & $\begin{array}{l}\text { parking areas within } \\
\text { settlements }\end{array}$ \\
\hline $\begin{array}{l}\text { nature } \\
\text { recreational } \\
\text { trails }\end{array}$ & $\begin{array}{l}\text { flowerbeds and } \\
\text { decorative bushes } \\
\text { alongside roads, at } \\
\text { crossroads and in front } \\
\text { of individual buildings }\end{array}$ & $\begin{array}{l}\text { arrangements } \\
\text { alongside streams }\end{array}$ \\
\hline $\begin{array}{l}\text { parking } \\
\text { areas within } \\
\text { settlements }\end{array}$ & $\begin{array}{l}\text { arrangements } \\
\text { alongside streams }\end{array}$ & $\begin{array}{l}\text { nature recreational } \\
\text { trails }\end{array}$ \\
\hline $\begin{array}{l}\text { wooded } \\
\text { parking areas }\end{array}$ & $\begin{array}{l}\text { semi-public green } \\
\text { spaces in residential } \\
\text { areas }\end{array}$ & $\begin{array}{l}\text { flowerbeds and } \\
\text { alongside roads, at } \\
\text { crossroads and in } \\
\text { front of individual } \\
\text { buildings }\end{array}$ \\
\hline
\end{tabular}

\section{Use of the survey}

A relatively small sample was included in the survey (under 100), which is too small to be statistically representative of the general population of the town. As denoted in the sections above, a suitable comparison of results among pre-defined user groups (residents of single homes - multiresidential dwellings, migrants - locals) could not suitably be carried out. Differences by gender also were not characteristic with differences among age groups merely depicted. The results are thus presented in various and key points of the survey.

The entire survey can, despite several deficiencies, especially survey work and a more comprehensive spatial analysis, serve as a suitable base for a more comprehensive survey which could provide more concrete results. Conceptual departure points and suppositions were used, which can later be developed into a comprehensive hypothesis and used as useful work methods. In the spatial analysis work, for example, it would be prudent to supplement the method with the behavioural maps of B. Goličnik (2006) or similar tools. These also require more comprehensive preparation and implementation.

\section{Conclusion}

The aim of the survey, which included a questionnaire and spatial analysis, was to recommend a concept for green and open spaces for Grosuplje and general guidelines for their arrangement. With the aid of the obtained results, individual problems related to green areas, open spaces and Grosuplje's appearance were ascertained with the needs of the respondents for specific types of such areas presented. First, safe and pleasant cycling and pedestrian paths in the town must be arranged, since both analyses established this to be a problem which needs to be resolved to enable the upgrade of the town's green areas. These will, in the future, have to be quantitatively supplemented through the arrangement of new semi-public and public green areas as well as park arrangements alongside residential areas at the town's periphery. The contents should be defined in terms of needs, assessed on the basis of the density and population of a defined area and based on possibilities of access to other similar areas in the nearby surroundings. Based on the finding that the problem of quality arrangement and maintenance of open spaces and urban green areas exists, these elements need to be improved. Attention should especially be focused on the suitable supplementation of city furniture. Existing areas deemed as public areas having limited time access should continue to remain key central green areas. Several contents (children's playgrounds and sport fields) should also be included in selected new areas within the scope of quantitative supplementation of urban green areas. Recreational outskirt areas should be supplemented in terms of paths, rest areas and information infrastructures. For the design of a more qualitative urban image, a dedicated design of the centre, urban roads and access areas should be suggested based on spatial analyses and partially on the results of the survey. The arrangement of key roads and the centre must be comprehensive. Leafy trees for tree avenues and other sub-dividing vegetation belts should be used in design, which will improve the structure of areas also at entrance points. Today, these define the areas of business zones. In the central part in which the town centre will be designed, several architectural changes which will significantly affect the appearance of this area are planned. It is recommended that regional arrangements alongside new buildings include a part of the street area, which in addition to aesthetics and representation, will also acquire an important social connection role. Therefore, the possibilities that the open space and green areas currently offer should be upgraded. Qualitatively arranged public green areas need to be created while exploiting the town's advantage of being located in a regionally interesting space. Urban green areas should connect to outskirt areas with safe connections, thereby concluding an experience circle that will lead the user of the space in a relatively small area through a whole variety of content and types of green areas. This will provide the user with numerous possibilities for activities and increased quality of living.

In the two years since the commencement of the survey, the state of urban green areas has already changed somewhat. New elements of city furniture have been added to the space; among the most important are benches and, upon brief observation, it can be established that now more people spend time at individual areas. Minimal interventions have thus, based on recognised problems, already improved the state and quality of a space.

As in Grosuplje, other similar smaller urban settlements also possess a rich and an important regional hinterland advantage. Regarding physical obstacles, an analysis of the state and success of existing green areas and needs of the residents 
for such areas is more manageable and more feasible. The profession and urban offices should as a rule, thus be able to more easily cooperate with each other. A thorough interpretation of needs and wants, and cooperation and planning will provide both departure points and good possibilities for effective creation of a quality living environment.

\section{Klara Sulič, Landscape Architect}

Luz, d. d., Ljubljana

E-mail: klara.sulic@luz.si

Dr. Ana Kučan, Landscape Architect, Associate Professor University of Ljubljana, Biotechnical Faculty, Department of Landscape Architecture, Ljubljana

E-mail: ana.kucan@bf.uni-lj.si

\section{Notes}

[1] The survey of green areas and open spaces in Grosuplje was carried out within the scope of a thesis entitled "Analysis of needs of public green areas as an aid to their arrangement" (author: K. Sulič, mentor: A. Kučan, co-mentor: D. Kos), at the Department of Landscape Architecture, Biotechnical Faculty, University of Ljubljana. The survey was carried out in 2006.

\section{References}

Dimitrovska Andrews, K., in Repič Vogelnik, K. (1995) Urbanistični kriteriji, normativi in standardi za prostorsko planiranje in urbanistično načrtovanje v Republiki Sloveniji: poročilo o delu v letih 1993 in 1994. Ljubljana, Urbanistični inštitut Republike Slovenije.

Doležal, M. (1991) Pregled zelenih površin in možnost njihove povezave v sistem na ožjem območju mesta Ljubljane. Diploma thesis. Ljubljana, Biotehniška fakulteta, Oddelek za krajinsko arhitekturo.

Francis, M. (2003) Urban Open Space: Designing for User Needs. Washington DC, Island press.

Goličnik, B. (2006) Vedenjski zemljevidi ljubljanskih trgov in parkov: Novi izzivi in pogledi na načrtovanje in urejanje prostora. Ljubljana, Urbani izziv publikacije.

Goličnik, B. (2008) ATP javnih prostorov, in: Simoneti, M., in Marinček, P. (eds.) Odprt javni prostor: načrtovanje, upravljanje, vzdrževanje, pp. 40-45. Ljubljana, Društvo krajinskih arhitektov Slovenije.

Goličnik, B., in Šuklje Erjavec, I. (2006) Potrebe, navade in pričakovanja prebivalcev $\vee$ stanovanjskih krajinah, in: Simoneti, M., in Gazvoda, D. (eds.) Stanovanjske krajine: trendi, perspektive, pp. 34-37. Ljubljana, Biotehniška fakulteta, Oddelek za krajinsko arhitekturo.

Marcus, C. C., Francis, C. (1998) People Places. New York, John Wiley \& Sons, Inc

Polič, M. (1996) Mesto, javni prostor in ljudje, in: Hudoklin, J. (ed.) Urejanje odprtega prostora $v$ urbanem okolju. Zbornik letnega strokovnega srečanja Društva krajinskih arhitektov Slovenije, pp. 36-40. Ljubljana, Društvo krajinskih arhitektov Slovenije.

Polič, M. (2000) Izkušnja narave v mestu, in: Marinček, P., Matjašec, D., in Simoneti, M. (eds.) Narava $v$ mestu. Med načrtovanim in spontanim, pp. 9-14. Ljubljana, Društvo krajinskih arhitektov Slovenije. 